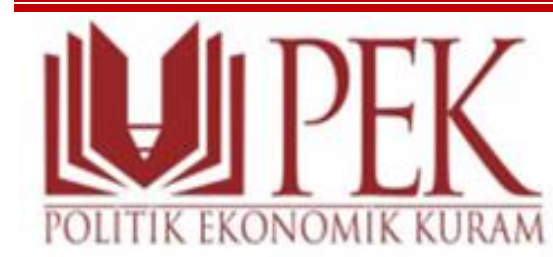

2020, Cilt 4, Sayı 2, 242-254

\section{POLITIK EKONOMIKK KURAM}

E-ISSN: 2587-2567

https://dergipark.org.tr/tr/pub/pek

Doi: 10.30586/pek.826336

Makale Geliş Tarihi: 15.11.2020

Makale Kabul Tarihi: 12.12.2020

Araştırma Makalesi

\title{
Türkiye'de Konut Sektöründeki Ortalama Karlılığın Konut Yatırımlarına ve Konut Fiyatlarına Etkisi
}

\author{
Cenap Mengü TUNÇAY ${ }^{1}$ \\ Effects of Average Profitability Residential Investment and Housing Price in the Housing \\ Sector in Turkey
}

\begin{abstract}
In the theory of economics, if the quantity of a good or service supplied in the market is more than the quantity of demanded, the market prices of that good or service are expected to decrease. In the housing market in Turkey, although the quantity of housing supplied is more than the quantity of housing demanded, it is seen that the housing prices are increasing in the national currency. It can be said that among the reasons for this situation, which is contrary to the theory, the increase in the costs of the construction sector as well as the high profitability can be effective. In this study, it has been tried to determine whether the housing prices in national currency which show a reverse trend predicted by the theory can be related with the profitability of the sector, by considering the balance of the housing market in Turkey and making to be associated with profitability in the housing sector of new housing investment. According to the used statistics, it can be concluded that it causes an increase or a limited downward trend in housing prices because of the fact that the housing investors or producers in Turkey have the high average unit profitability and not to face with the sales challenges stemming from the high demand for housing.
\end{abstract}

Keywords: Housing Investment, Housing Prices, Housing Sector.

JEL Codes: E22, O18, R31

Öz

İktisat kuramında bir mal ya da hizmetin piyasada arz edilen miktarı, talep edilen miktarından fazla ise o mal ya da hizmetin piyasa fiyatlarının düşmesi beklenir. Türkiye'de konut piyasasında, arz edilen konut miktarının, talep edilen konut miktarından fazla olmasına rağmen, konut fiyatlarının ulusal para cinsinden artmakta olduğu görülmektedir. Teoriye ters bir şekilde meydana gelen bu durumun oluşmasıyla ilgili teorik nedenler arasında inşaat sektörünün maliyetlerinin yükselmesinin yanında, karlılıkların yüksekliğinin de etkili olabildiği söylenebilmektedir. Bu çalışmada, Türkiye'de konut piyasasının dengesi gözetilerek ve yeni konut yatırımlarının konut sektöründeki karlılıkla ilişkilendirilmesi yapılarak, konut piyasasında oluşan ulusal para cinsinden konut fiyatlarının teorinin öngördüğü yapının tersine bir eğilim göstermesinin, sektör karlıllğı ile ilişkilendirilip ilişkilendirilemeyeceği ile ilgili bir tespitte bulunulmaya çalışılmıştır. Kullanılan istatistiklerden hareketle, Türkiye'de konut yatırımcılarının ya da üreticilerinin, yüksek ortalama birim karlılığa sahip olmaları ve konuta olan yüksek talepten kaynaklı olarak göreli satı̧̧ zorluklarıyla karşılaşmamalarının, konut fiyatlarında artma veya kısıtlı bir düşme eğiliminin oluşmasına neden olduğu sonucuna varılabilmektedir.

Anahtar Kelimeler: Konut Yatırımları, Konut Fiyatları, Konut Sektörü

${ }^{1}$ Dr. Öğr. Üyesi, Ankara Hacı Bayram Veli Üniversitesi iỉBF Iktisat Bölümü 


\section{Giriş}

İktisat kuramında bir mal ya da hizmetin piyasada arz edilen miktarı, talep edilen miktarına oranla fazla ise o mal ya da hizmetin piyasa fiyatlarının düşmesi beklenir. Türkiye'de konut piyasasında arz edilen konut miktarının, talep edilen konut miktarından fazla olmasına rağmen piyasada konut fiyatlarının yıllar itibariyle ulusal para cinsinden artmakta olduğu görülmektedir.

İktisat literatüründe yapılan çalışmalardan yola çıkılarak teorinin ortaya koyduğu ilişkiye ters bir şekilde meydana gelen bu durumun oluşmasıyla ilgili birçok neden sıralanabilmektedir. Bu duruma inşaat sektörünün maliyet unsurlarından olan arsa maliyetlerinin inşaat yapı maliyetleri ile yükselmesinin yanı sıra sektördeki karlılıkların yüksekliğinin de etkili olabilmesi söz konusudur.

Bu çalışmada, Türkiye'de konut piyasasında yıllar itibariyle arz talep dengesinin analizi yapılarak, piyasada oluşan fiili durumun, konut sektöründeki karlılıkla ilişkilendirilmesi yapılarak, piyasada oluşan ulusal para cinsinden konut fiyatlarının teorinin öngördüğü yapının tersine bir eğilim göstermesinin, sektör karlılığı ile ilişkilendirilip ilişkilendirilemeyeceği ile ilgili bir tespitte bulunmaya çalışılmaktadır.

Çalışmada kullanımına ihtiyaç duyulan sayısal verilerin istatistiklerinin mevcut olduğu yıllar, çalışmanın kapsamında bir kısıt oluşturmakla beraber, konut üretiminde bulunan ya da konut yatırımlarını yapan inşaat firmalarının ekonomide aynı zamanda konut dışı inşaat faaliyetlerinde bulunmalarından kaynaklı olarak inşaat sektörü karlılık oranlarının çalışmada kullanılmasının yanıltıcı olabileceği düşüncesiyle, Türkiye Cumhuriyet Merkez Bankası (TCMB) sektör bilançolarından elde edilebilecek sektör karlılık oranları çalışmada kullanılmamıştır. Sektör bilançolarındaki karlılık oranlarının, inşaat firmalarının faaliyet dallarından sadece biri olan konut üretimi ile ilgili yapılabilecek iktisadi bir analizle ilgili bir çıkarıma aracı edilmesi doğru olmayacağından, çalışmada konut sektöründeki ortalama birim karlılıklar ele alınmış ve birim karlılıkların konut fiyatları üzerinde etkili bir unsur olup olmayabileceği ile ilgili çıkarımlar yapılmaya çalışılmaktadır.

\section{Konut Piyasasında Konut Arz ve Talebini Belirleyen Faktörler ile Konut Yatırımlarında Karlılık}

İktisat teorisinde bir mal ya da hizmetin talep edilen ve arz edilen miktarlarını belirleyen faktör, ceteris paribus varsayımına uygun olarak arz ve talebi belirleyen tüm faktörler değişmiyorken, $o$ mal veya hizmetin fiyatı olarak ifade edilir. Mal ya da hizmetin arz edilen miktarı, malın fiyatı ile doğru orantılı değişme gösterirken; mal ya da hizmetin talep edilen miktarı, malın fiyatı ile ters orantılı değişme göstermektedir.

Mal veya hizmet piyasasında serbest piyasa koşullarının olması durumunda, mal ya da hizmetin fiyatının denge fiyatının, üzerinde olması; arz edilen miktarın, talep edilen miktara oranla fazla olması durumunu doğurmakta ve bu durum, mal ya da hizmetin fiyatının düşme eğilimine girmesine neden olmaktadır. Mal veya hizmet piyasasında serbest piyasa koşullarının olması durumunda, mal ya da hizmetin fiyatının, denge fiyatının altında olması; talep edilen miktarın, arz edilen miktara göre fazla olması durumunu doğurmakta ve bu durum, mal ya da hizmetin fiyatının artma eğilimine girmesine neden olmaktadır.

Konut piyasasında da alım satıma konu olan konutların arz ve talep edilen miktarları, teorik olarak konut fiyatlarının bir fonksiyonu olmakla beraber, söz konusu malın konut olması, kısa ve uzun dönemde spesifik bir piyasa dengesi ortaya çıkarmaktadır.

Mishkin (2018:693-702)'e göre, konut yatırımlarının tamamlanması zaman aldığından ve mevcut konutlardaki yıpranma yavaş gerçekleştiğinden, önceki konutlar ile yeni konutları içeren konut stokunun kısa vadede sabit olduğu ve dolayısıyla konut arz eğrisinin kısa vadede dikey bir yapıya 
sahip olduğu ortaya konmaktadır. Ancak, yeni konut inşaatları ya da yeni konut yatırımları, konut fiyatları ile doğru orantılı ilişki içinde olmaktadır. Tunç (2020:40)' a göre, konut arzının kısa vadede fiyat esnekliği düşük olup, kısa dönem konut arz eğrisi, dike yakın pozitif eğimli yapıya sahiptir. Konut üretim süreci; konut yapım planları, yapı izinleri, satış ve pazarlama süreçleri ile birlikte ele alındığında, bir yıldan fazla zaman almakta, dolayısıyla kısa vadede üretim, fiyat değişimlerine cevap verememektedir. Dolayısıyla kısa dönemde meydana gelen bir talep artışı, göreli olarak (uzun dönemde ortaya çıkabilecek bir artışa oranla) daha çok fiyat artı̧̧1 yaratmaktadır. Bu artan fiyatlar arzı da arttırmaktadır.

İktisat literatüründe konut arz ve talebini konu alan çalışmalardan Tunç (2020:5)'un çalışmasına göre, ekonomide konut talebini etkileyen faktörler; gelir düzeyi, piyasa faizleri, işsizlik oranı, nüfus artı̧̧1, göç, kentleşme, aile yapısı değişimi, ev sahibi olma güdüsü, miras bırakma güdüsü, spekülasyon yapma, kalite kaynaklı konut edinme isteği olarak ele alınmaktadır. Hatipoğlu ve Tanrıvermiş (2017:49)'in çalışmasına göre, nüfusun yaş dağılımı, hanehalkı büyüklüğü, gayri safi yurtiçi hasıla (GSYİH), kişi başı gelir, istihdam, büyüme oranı, faiz oranı ve konut kredileri de konut talebini etkilemektedir.

Konut arzını etkileyen faktörlere bakıldığında; Tunç (2020:5)'a göre, piyasa faiz oranları, inşaat maliyetleri ve hükümet politikaları konut arzını etkileyen unsurlar olarak sıralanmaktadır. Hatipoğlu ve Tanrıvermiş (2017:49-67)' in çalışmasına göre ise, arsa üretimi, inşaat sektörünün GSYIH içindeki payı, inşaat sektörüne açılan krediler, inşaat ruhsatları, istihdam düzeyi unsurları sıralanmaktadır. Dolayısıyla inşaat maliyetlerinden kaynaklı olarak karlılık da konut arzını etkilemektedir. Konut arzını belirleyen değişkenlerden biri de konut finansman maliyetlerinin düşmesidir (Gözübüyük ve Koy, 2020:1).

Konut piyasasında konut arz ve talebini etkileyen bu değiş̧kenlerin zaman içindeki değişimleri, değişim büyüklükleri ile orantılı olarak konut fiyatlarında dalgalanmalara sebep olmakta, ancak fiyatların genellikle artış yönünde bir trend izlemesini değiştirmemektedir. Diğer bir ifadeyle, zaman içinde global ekonomide genel olarak konut fiyatlarında belirli ölçüde dalgalanmalar görülmekle birlikte, konut fiyatları artış eğilimi içinde bulunmaktadır. $\mathrm{Bu}$ olgu, küresel gayrimenkul danışmanlık şirketi Knight Frank (2020)'ın yayınlamış olduğu Global Konut Fiyat Endeksi'nde ele alınan ülkelerin çoğunluğunda konut fiyatlarının değişen oranlarda artmakta olmasıyla da kendini göstermektedir. Genel olarak artış trendinde olan fiyatlar, konut üreticilerinin karlılıklarını arttırmakta ve bu nedenle konut üreticilerinin konut üretim motivasyonu da artış göstermektedir.

Konut piyasasında arz ile dolaylı olarak talebi etkileyen ve ekonomide konut arz fazlasının ortaya çıkmasında etkili olabilecek önemli unsurlardan biri yeni konut yatırımları olmaktadır. Golland (1996:6)'a göre ekonomide yeni konut arzında etkili olan üç faktör bulunmaktadır. Bu faktörler, konut sektörüne devlet tarafından yapılan doğrudan sermaye yatırımları, konut üretimi ve alımı için verilen devlet teşvikleri, özel sektörde faaliyet gösteren konut üretiminde bulunan şirketlerin karlılık oranlarındaki değişim unsurları olup, rekabetçi ortamda birinci ve ikinci unsurları ölçme zorluğu olduğundan, üçüncü unsur olan karlılığın konut yatırımını belirlemedeki etkisi incelenebilmektedir. Golland (1996:7)'a göre konut yatırımlarındaki kar, konut fiyatından, arsa ve inşaat yapı maliyetlerinin çıkarılmasıyla elde edilmekte ve konut fiyatı arttıkça karın artacağı ve Neoklasik İktisat teorisine uygun olarak konut yatırımlarının artış göstereceği ortaya konmaktadır. 


\section{Türkiye'de Konut Piyasası Analizi, Yeni Konut Yatırımları ve Konut Stoku}

Türkiye'de konut piyasasında zaman içinde oluşan konut fiyatlarının global konut fiyat endeksinde ortaya konulan duruma uygun olarak, artış trendinde olduğu anlaşılmaktadır. Grafik 1, Türkiye'de konut fiyat endeksi, yeni konut fiyat endeksi ve metrekare başına konut birim fiyatlarının yıllar itibariyle değişimlerini göstermektedir. Grafiğe göre 2013 yılından 2020 yılına kadar hem endeks değerlerinin hem de konut birim fiyatlarının arttığı görülmektedir.

Grafik 1.Türkiye'de Y1llara Göre Yeni Konut Fiyat Endeksi, Konut Fiyat Endeksi ve Konut Birim Fiyatları $\left(\mathrm{TL} / \mathrm{m}^{2}\right)$

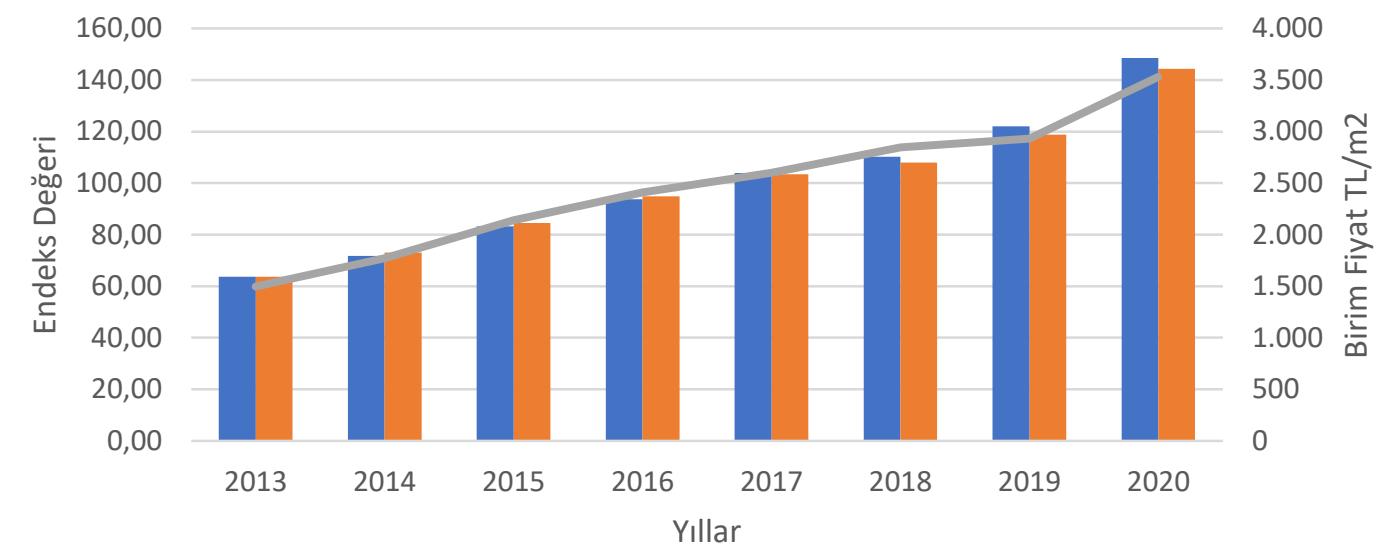

Yeni Konutlar Fiyat Endeksi $\quad$ Konut Fiyat Endeksi $\quad$ Konut Birim Fiyatları TL /m2

Kaynak: Türkiye Cumhuriyet Merkez Bankası (TCMB), Elektronik Veri Dağıtım Sistemi (EVDS), Konut ve İnşaat İstatistikleri - Yeni Konutlar Fiyat Endeksi - Konut Fiyat Endeksi Konut Birim Fiyatları verilerinden oluşturulmuştur. Erişim: https://evds2.tcmb.gov.tr/index.php?/evds/serieMarket/collapse_26/5949/DataGroup/turkish/bie hkfe/

Grafik 1'de görüldüğü gibi konut birim fiyatları ve fiyat endeksi ile yeni konut fiyat endeksleri artarken, teorik olarak konut yatırımlarının ya da konut arzının artması beklenmektedir. Teoriye göre beklenen durumun gerçekleşip gerçekleşmediğini görmek için Grafik 2 oluşturulmuştur. Grafik 2'ye bakıldığında, teoriye uygun olarak, konut fiyatları ulusal para cinsinden artış gösterirken, konut arzının da artmakta olduğu görülmektedir. Yabancı para ABD Doları cinsinden fiyatların ise zaman içinde 2016 yılına kadar neredeyse sabit, 2016 yılından sonra azalma gösterdiği görülmektedir. Hem ulusal para cinsinden hem de ABD Doları cinsinden fiyatların iki dönem hareketli ortalamalarına göre trend grafiklerine bakıldığında, TL cinsinden fiyatların artma yüzdelerinin, ABD Doları cinsinden fiyatların azalma yüzdelerine göre daha fazla olduğu görülmektedir. 
Grafik 2. Türkiye'de Yıllara Göre Konut Birim Fiyatları ve İkamet Amaçlı Daire Sayıları

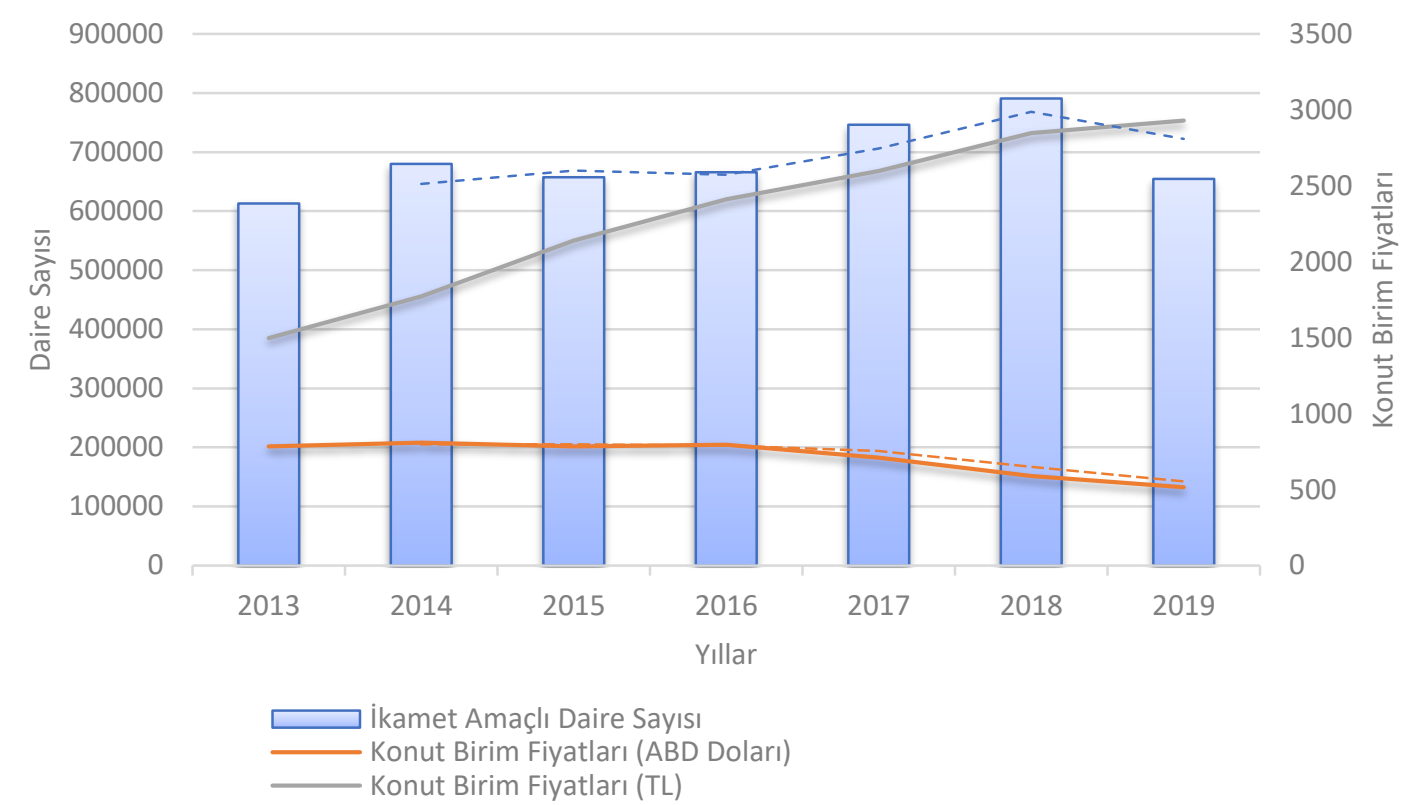

Kaynak: Türkiye Cumhuriyet Merkez Bankası (TCMB), Elektronik Veri Dağıtım Sistemi (EVDS), Konut ve İnşaat İstatistikleri - Konut Birim Fiyatları - Yapı Kullanma İzin Belgelerine Göre İnşaat İstatistikleri ve Kurlar-Döviz Kurları - ABD Doları Döviz Satış verilerinden oluşturulmuştur. Erişim:

https://evds2.tcmb.gov.tr/index.php?/evds/serieMarket/collapse_26/5949/DataGroup/turki $\underline{\text { sh/bie_hkfe/ }}$

Erişim: https://evds2.tcmb.gov.tr/index.php?/evds/serieMarket/collapse_26/5949/DataGroup/turkish/bie $\underline{\mathrm{hkfe} /}$

Türkiye'de konut sektöründe yıllara göre arz ve talep dengesini analiz etmek amacıyla arzı temsilen satı̧sa sunulmaya hazır iskanlı daire sayıları istatistiklerine ve talebi temsilen ilk el konut satış istatistiklerine bakılarak yıllar itibariyle konut arzı ya da talebinde eksiklik ya da fazlalığın olup olmadığına yönelik tespit yapmak mümkün olabilmektedir. 2013 yılından 2019 yılına kadar her bir yıl içerisinde satışa sunulmaya hazır iskanı alınmış yeni konut daire sayılarının, aynı yıllarda yapılan ilk el konut satış rakamlarının üzerinde olduğu görülmektedir. Diğer bir ifadeyle, ele alınan yıllar itibariyle konutların arz edilen miktarının, talep edilen miktarından fazla olduğu, dolayısıyla arz fazlalı̆̆ görülmektedir. Bu durum Grafik 3'de izlenebilmektedir. Satışa sunulan iskanlı daire sayısı ile aynı dönemde yapılan ilk el konut satış adetleri arasındaki fark, arz edilen miktar fazlalı̆̆ını oluşturmaktadır. Talebe göre arz edilen miktarda göreli artış, yıllar içinde devam ederken, ulusal para cinsinden yeni konut fiyatları teoriye ters bir şekilde artmaya devam etmektedir. 
Grafik 3. Türkiye'de Yıllara Göre İskanlı Daire Sayıları ve İlk El Konut Satışları ile Yeni Konut Fiyat Endeksi

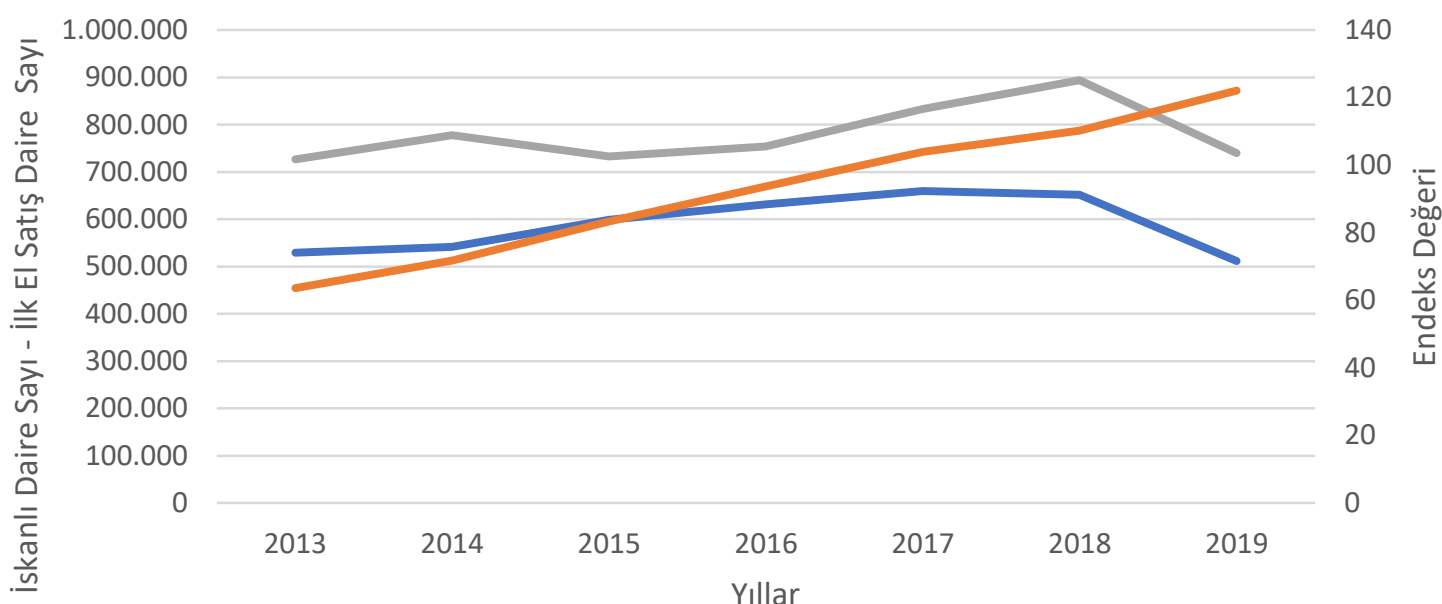

Konut Ilk El Satış —Toplam İskanlı Daire Sayısı $\quad \longrightarrow$ Yeni Konut Fiyat Endeksi

Kaynak: Türkiye Cumhuriyet Merkez Bankası (TCMB), Elektronik Veri Dağıtım Sistemi (EVDS), Konut ve İnşaat İstatistikleri, Konut Satış İstatistikleri- İlk El Satış, Yapı Kullanma İzin Belgelerine Göre İnşaat İstatistikleri, Yeni Konutlar Fiyat Endeksi verilerinden oluşturulmuştur.Erişim:

https://evds2.tcmb.gov.tr/index.php?/evds/serieMarket/collapse_26/5949/DataGroup/turkish/bie $\underline{\mathrm{hkfe} /}$

Ele alınan yıllar içerisinde meydana gelen yeni konut fiyat endeksindeki artış, söz konusu yıllar içinde mevcut enflasyondan kaynaklı olarak doğal karşılanabilecek olsa da; Trading Economics (2020) verilerine göre, 2013 y1lından 2019 y1lına kadar ABD enflasyonunun \%2-\%2,5 arasında seyir göstermesinden ötürü, neredeyse reel fiyatlar olarak sayılabilecek ABD Doları cinsinden fiyatların 2013 yılından 2016 yılına kadar arz edilen miktar fazlası olmasına rağmen, sabite yakın bir seyir göstererek, 2016 yılından sonra oldukça düşük oranda bir azalma göstermesi, konut fiyatlarının aşağı yönlü katılığının bir göstergesi olarak kabul edilebilir. Grafik 3 'te yer alan her bir yıl için satışa konu olmamış farklı sayılarda iskanlı konutun, toplam konut stokuna ilave olduğunu söylemek mümkündür. Toplam konut stokuna y1llar itibariyle ilaveler, Grafik 4'de çizgi grafikle gösterilmektedir. Grafiğe göre 2013 ve 2014 yıllarında satışa hazır iskanlı dairelerle ilk el satışı yapılan daire sayısı arasında açıklık fazla olduğundan konut stokuna ilaveler göreli olarak yüksek olmuş, ancak 2014 yılından itibaren 2015 ve 2016 yıllarında satışa hazır iskanlı dairelerin daha yüksek bir oranda ilk el satışlarının olmasıyla, söz konusu yıllarda konut stokuna ilaveler azalma göstermiştir. 2017 yılından itibaren 2019 yılına kadar konut arzını temsil eden iskanlı daire sayısı ile ilk el konut satış adetleri arasındaki farklar tekrar açılmaya başlayarak, konut stokuna ilaveler artış göstermeye başlamıştır. 
Grafik 4. Türkiye’de Yıllara Göre İlk El Konut Satış İstatistikleri, İskanlı Daire Sayıları ve Konut Stokuna İlave

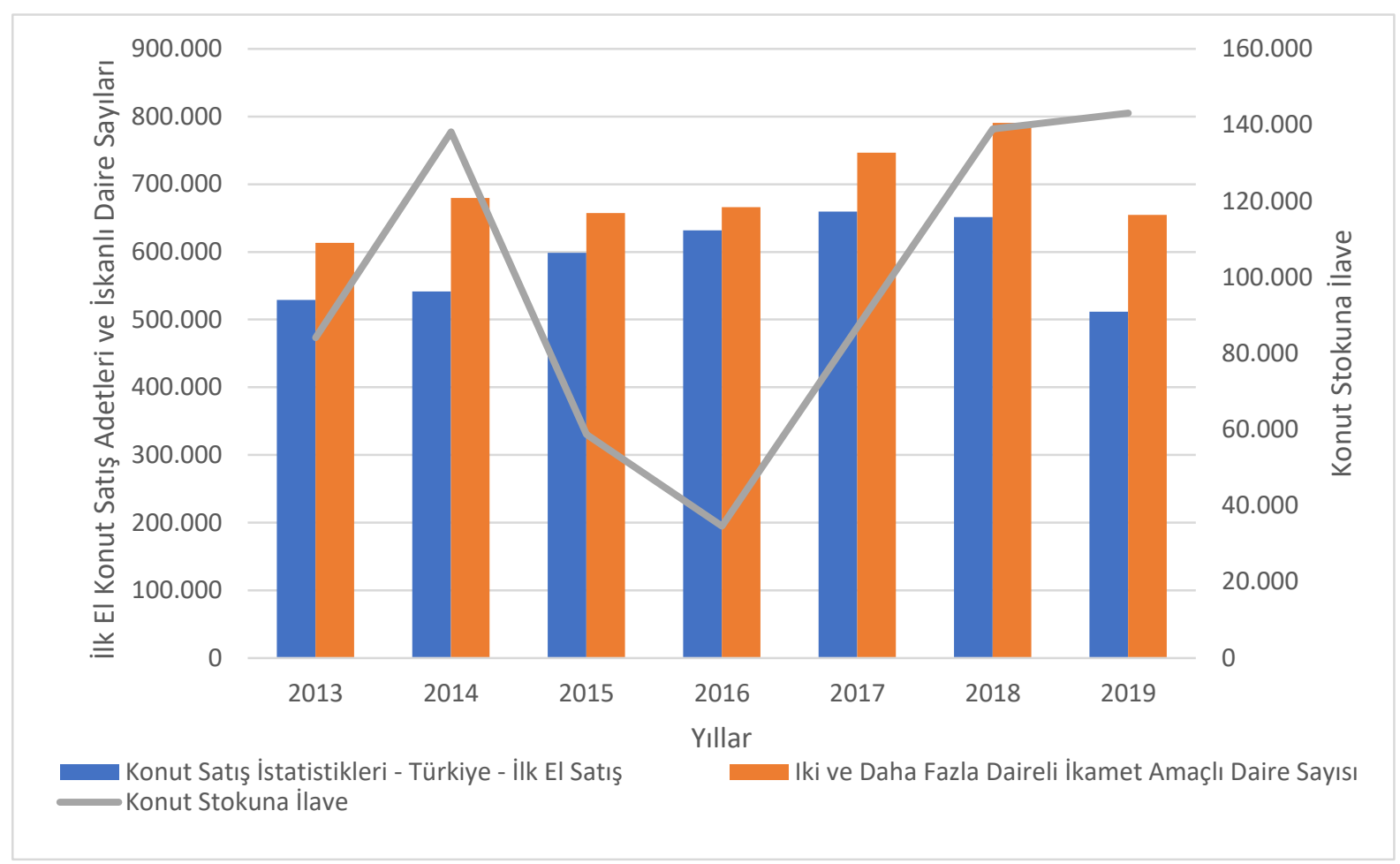

Kaynak: Türkiye Cumhuriyet Merkez Bankası (TCMB), Elektronik Veri Dağıtım Sistemi (EVDS), Konut ve İnşaat İstatistikleri, Konut Satış İstatistikleri- İlk El Satış, Yapı Kullanma İzin Belgelerine Göre İnşaat İstatistikleri - İki ve Daha Fazla Daireli İkamet Amaçlı Daire Sayısı verilerinden oluşturulmuştur.

Erişim: https://evds2.tcmb.gov.tr/index.php?/evds/serieMarket/collapse_26/5949/DataGroup/turkish/bie_ hkfe/

Grafik 3'de ve Grafik 4'de gösterilen yıllara göre oluşan arz fazlalığının, konut fiyatlarındaki artışla birlikte düşünüldüğünde, Neoklasik İktisat Teorisi'nin öngörüsüne uygun bir değişme gösterdiğini söylemek mümkün olmamaktadır. Teorik olarak konut yatırımlarının karlılık ile doğru orantılı bir fonksiyonel ilişki içinde olması sebebiyle söz konusu arz fazlalığının ekonomideki karlılık oranlarıyla birlikte bir değerlendirmesinin yapılması da gerekli olmaktadır.

\section{Türkiye'de Konut Sektöründe Ortalama Karlıı̆ı̆ı Konut Yatırımları ile İliş̧kisi ve Konut Fiyatlarma Etkisi}

Türkiye'de konut sektöründe ele alınan yıllar itibariyle konut stokuna yapılan ilaveler ve buna bağlı oluşan konut arzı fazlasının teorik olarak sektördeki karlılıkla ilişkilendirilebilirliği ile ilgili olarak konut yatırımlarının karlılık oranlarına bakmak gerekirse, konut üretiminde bulunan konut yatırımcılarının salt konut üretim faaliyetlerinden kaynaklı olabilecek karlılıklarının elde edilmesi gerekmektedir.

Türkiye'de konut inşaatı faaliyetlerinde bulunan inşaat firmaları, konut inşaatlarının dışındaki inşaat faaliyetleriyle de ilgili üretimde bulunabildiklerinden, TCMB Sektör Bilançoları'nda yer 
alan inşaat sektörü karlılık oranlarının kullanılması yerine, konut üretimi ile ilgili ortalama birim karlılıkların kullanılmasının daha doğru bir analiz olacağı düşüncesiyle konut sektörüne yönelik birim karlılıklar elde edilmeye çalışılmıştır.

Konut yatırımlarının birim karlılık hesaplamaları için sektördeki konut birim satış fiyatlarının istatistiki verileri yıllar itibariyle TCMB'den temin edilmiştir. Konut birim maliyetleri ise betonarme inşaat sınıflarına göre Hazine ve Maliye Bakanlığı istatistiklerinden temin edilmiştir. İnşaat sınıflarına göre ayrı maliyet değerlerinin ortalamaları alınarak her yıl için bir ortalama maliyet değerine ulaşılmıştır. Elde edilen veriler, Tablo 1'de yer almaktadır.

Tablo 1. Türkiye'de Yıllara Göre Bina İnşaatı Birim Maliyetleri (Mesken Betonarme Karkas Bina İnşaatı Maliyetleri) ve Birim Fiyatları (Konut Fiyat İstatistikleri ) (TL/M $\left.{ }^{2}\right)$

\begin{tabular}{|c|c|c|c|c|c|c|c|}
\hline & 2013 & 2014 & 2015 & 2016 & 2017 & 2018 & 2019 \\
\hline $\begin{array}{l}\text { Lüks } \\
\text { İnşaat M } \\
\text { Maliyeti }\end{array}$ & 1090,67 & 1175,74 & 1221,94 & 1302,1 & 1374,76 & 1516,36 & 1735,77 \\
\hline $\begin{array}{l}\text { 1. Sinıf } \\
\text { İnşaat } \mathrm{M}^{2} \\
\text { Maliyeti }\end{array}$ & 681,12 & 734,24 & 763,1 & 813,16 & 858,53 & 946,96 & 1083,99 \\
\hline $\begin{array}{l}\text { 2. Sinıf } \\
\text { İnşaat } \mathrm{M}^{2} \\
\text { Maliyeti }\end{array}$ & 454,74 & 490,21 & 509,47 & 542,89 & 573,18 & 632,22 & 723,71 \\
\hline $\begin{array}{l}\text { 3.Sinıf Ins } \\
\text { aat } \mathrm{M}^{2} \\
\text { Maliyeti }\end{array}$ & 322,05 & 347,17 & 360,81 & 384,48 & 405,94 & 447,75 & 512,54 \\
\hline $\begin{array}{l}\text { Ortalama } \\
\text { Maliyet }\end{array}$ & 637,145 & 686,84 & 713,83 & $\begin{array}{l}760,657 \\
5\end{array}$ & $\begin{array}{l}803,102 \\
5\end{array}$ & $\begin{array}{l}885,822 \\
5\end{array}$ & $\begin{array}{l}1014,00 \\
3\end{array}$ \\
\hline \multicolumn{8}{|c|}{$\begin{array}{l}\text { Kaynak: Hazine ve Maliye Bakanlığı, Bina İnşaat Maliyet Bedelleri } \\
\text { Erişim : https://www.alomaliye.com/kategori/diger-mevzuat/m2-maliyetleri/ }\end{array}$} \\
\hline & 2013 & 2014 & 2015 & 2016 & 2017 & 2018 & 2019 \\
\hline $\begin{array}{l}\text { Türkiye } \\
\text { Konut } \\
\text { Birim } \\
\text { Fiyatları }\end{array}$ & 1496,61 & 1771,59 & 2140,3 & 2410,99 & 2598,62 & 2848,3 & 2930,51 \\
\hline \multicolumn{8}{|c|}{$\begin{array}{l}\text { Kaynak: Türkiye Cumhuriyet Merkez Bankasi (TCMB), Elektronik Veri Dağıtım Sistemi } \\
\text { (EVDS), Konut ve Inşaat İstatistikleri - Konut Birim Fiyatları } \\
\text { https://evds2.tcmb.gov.tr/index.php?/evds/serieMarket/collapse_26/5949/DataGroup/turkis } \\
\text { h/bie_hkfe/ }\end{array}$} \\
\hline
\end{tabular}

Her yıl için ortalama konut birim fiyatlarından ortalama maliyet rakamları çıkarıldığında her yıl için ortalama birim karlılığa ulaşılabilmektedir. Hesaplanan bu karlılık, arsa maliyetleri istatistiklerinin mevcut olmaması nedeniyle bu maliyetlerin dışarda bırakılarak hesaplanmasıyla oluşan maliyetler olmaktadır. 
Türkiye'de arsa maliyetleri ile ilgili bir istatistik bulunmamaktadır. Timetürk (2008)'e göre, genellikle kat karşılı̆̆ 1 arsa tahsislerinde oranlar yüzde elli düzeyinde olmaktadır. Bu orandan hareketle, ortalama birim maliyetlerinin yarısı kadar da arsa maliyetinin yapıldığı kabul edilerek, arsa dahil olmak üzere maliyetlere oranla diğer bir karlılık hesaplaması da yapılmıştır.

Konut sektöründe konut üretiminde bulunan konut yatırımcılarının, konut maliyetlerine oranla elde ettikleri birim karlılık rakamları ile sektördeki toplam üretilmiş satışa hazır iskanlı dairelerin satış oranlarını Grafik 5'de karşılaştırdığımızda ele alınan yıllar itibariyle satışa hazır iskanlı dairelerin ortalama olarak oldukça büyük bir kısmının ilk el satışa konu olduğu görülmekte ve satış hacimleri artarken, sektör üreticilerinin maliyetlere oranla karlılıklarının artmakta olduğu görülmektedir. $\mathrm{Bu}$ oran, 2013 yılında 1,5 civarındayken 2015 yılında 2 değerine ulaşmış, 2019 yılına kadar da 2 değerinin üzerinde seyretmiştir.

Grafik 5. Türkiye'de Yıllara Göre Konut Yatırımlarının Maliyetlere Oranla Karlılığı ile Toplam İskanlı Dairelerin Satış Oranları

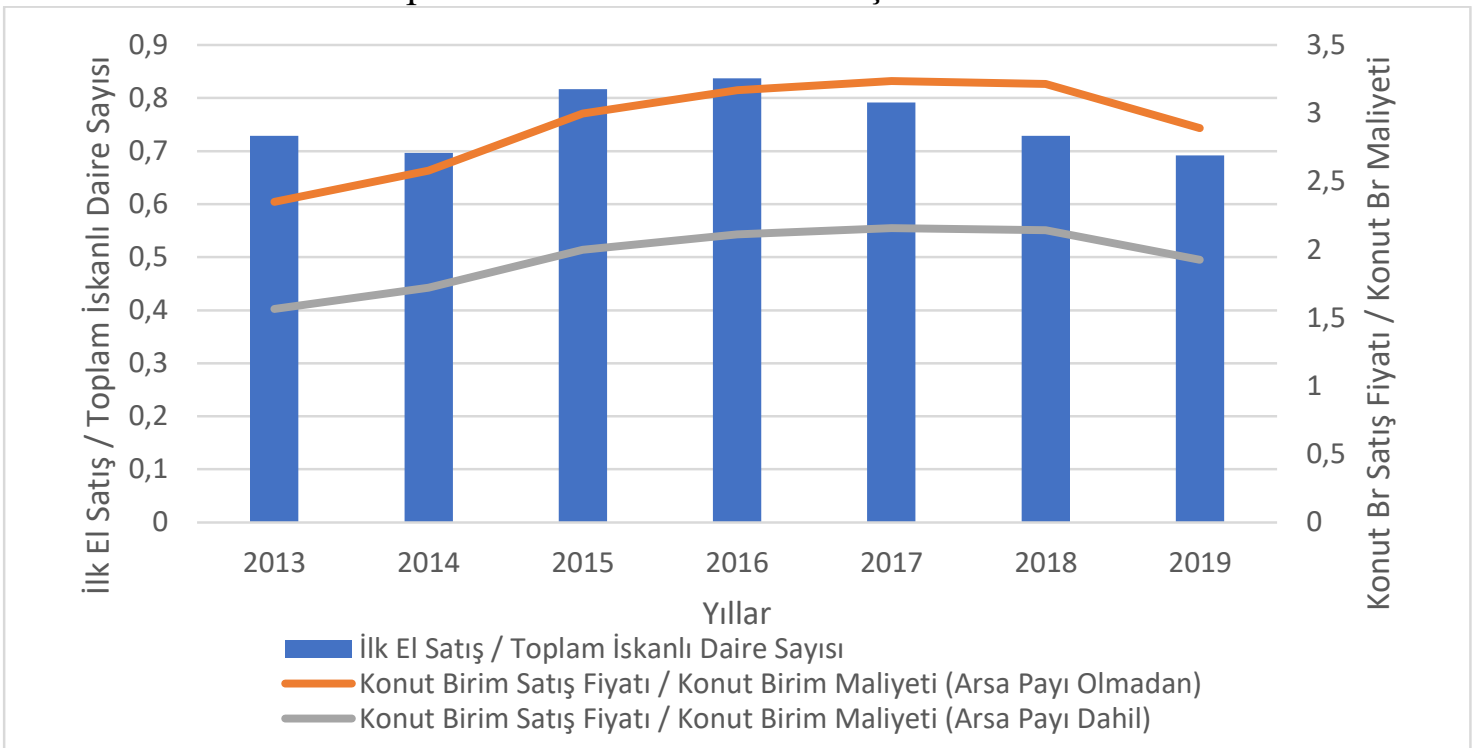

Kaynak: Türkiye Cumhuriyet Merkez Bankası (TCMB), Elektronik Veri Dağıtım Sistemi (EVDS), Konut ve İnşaat İstatistikleri, Konut Satış İstatistikleri- İlk El Satış, Yapı Kullanma İzin Belgelerine Göre İnşaat İstatistikleri verilerinden ve Hazine ve Maliye Bakanlı̆̆ı, Bina İnşaat Maliyet Bedelleri verilerinden oluşturulmuştur. Erişim : https://evds2.tcmb.gov.tr/index.php?/evds/serieMarket/collapse_26/5949/DataGroup/turkish/bie hkfe/ Erişim : https://www.alomaliye.com/kategori/diger-mevzuat/m2-maliyetleri/

Grafik 5'e göre ele alınan değişkenlerin yıllara göre seyrinden hareketle, üretilen konutların, ortalama olarak \%70 ve üstü oranlarda ilk el satışa konu olarak talep edildiği görülmekte ve maliyetlere oranla sektör karlılığının da artış gösterdiği görülmektedir. Buradan hareketle maliyetlere oranla artan karlılıkların olması ve talep sorununun olmamasının konut üreticilerinin fiyat düşürmemesine yol açtığı sonucuna ulaşmak mümkün olabilmektedir. Bununla beraber, düşük $\mathrm{ABD}$ enflasyonu nedeniyle neredeyse reel konut fiyatı olarak nitelendirilebilir olan ve Grafik 2'de görülen ABD Doları cinsinden oldukça düşük ölçüde gerçekleşen fiyat azalmaları görülmektedir. Ele alınan yıllar içerisinde ABD Doları'na yönelik kur beklentisi dikkate alındığında, ABD Doları cinsinden konut fiyatlarındaki azalmaların, konut üreticilerinin kurda artış 
beklemeleri nedeniyle satış hacmini arttırmak amacıyla yapılmış fiyat indirimleri olabileceği çıarımını yapabilmek de mümkündür. TCMB'nin 2013 - 2019 yılları arasındaki beklenti anketi istatistiklerine göre, ele alınan yıllar içinde ABD Doları kuruna yönelik kur artış beklentisi, Grafik 6'da yer almaktadır.

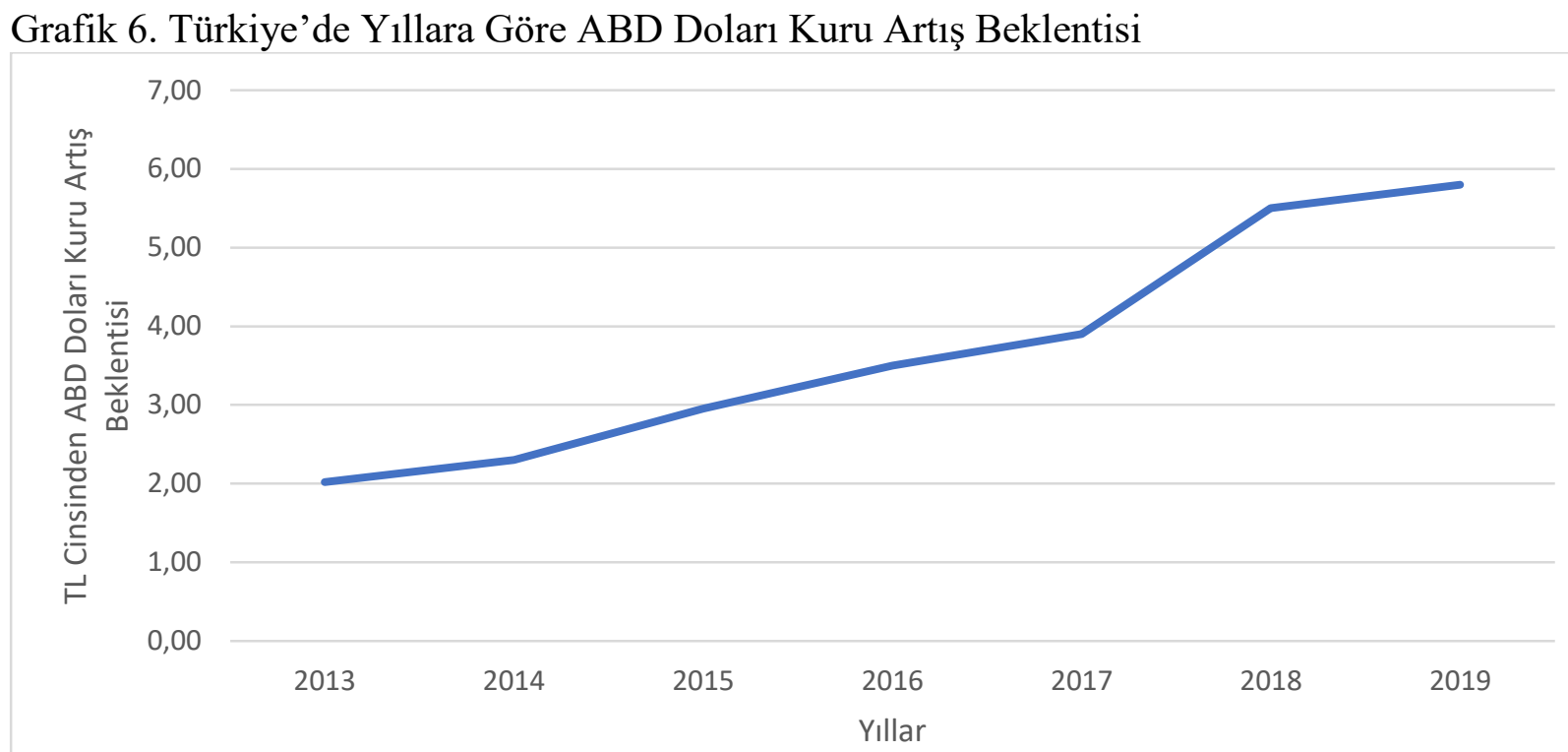

Kaynak: Türkiye Cumhuriyet Merkez Bankası (TCMB), Elektronik Veri Dağıtım Sistemi (EVDS), Beklenti Anketi İstatistikleri - Cari Y1l Sonu Bankalararası Döviz Piyasası ABD Dolar Kuru Beklentisi (TL), Erișim http://www.tcmb.gov.tr/wps/wcm/connect/TR/TCMB+TR/Main+Menu/Istatistikler/Egilim+Ank etleri/Beklenti+Anketi+Istatistikleri

Ekonomide ele alınan yıllar içerisinde kur artış beklentisinin yüksek olması, konut üreticilerinin, satı̧ hacimlerini arttırmak için ürettikleri konutların ABD Doları bazında fiyatlarında indirim yapabilmelerine de imkan tanıyabilmektedir. Kurdaki artış beklentisinin varlığı, Türk Lirası (TL) karşılı̆̆ satılan konutların bedelinin, spekülatif amaçla döviz alımına konu edilmesini sağlayabilmektedir. Uzun vadede kur artışının yarattı̆̆ döviz spekülasyonundan kaynaklı kazancın realize edilmesiyle TL cinsinden karlılıkların etkilenmemesi sağlanabilmektedir. Kur artış beklentisinin olduğu ekonomilerde konut satışlarından elde edilecek ulusal para cinsinden gelirin, döviz spekülasyonu amacıyla değerlendirilebilme olanağı, konutların daha rahat pazarlanması ve satı̧ hacminin arttırılabilmesi amacıyla konut üreticilerini belirli ölçüde fiyat indirimi yapmaya yöneltebilmektedir. Döviz kuru beklentileri ile konut sektöründeki karlılık unsurlarının dışında konut fiyatlarını etkileyen başka faktörler de vardır. İktisat literatüründe konut fiyatlarını etkileyen değişkenleri konu olan çalışmalardan Eryüzlü ve Ekici (2020:104)'nin çalışmasına göre, Türkiye'de döviz kurunun konut fiyatları üzerinde etkisi söz konusu olup, döviz kurundaki yükselmeler, konut fiyatlarının azalmasına sebep olmaktadır. Bu sonuç, kur artış beklentisinin varolduğu bir durumda ulusal para cinsinden elde edilen satış gelirlerinin döviz spekülasyonuna konu edilerek, satış hacmini arttırmak ve etkin pazarlama yapabilmek amacıyla konutların fiyatlarında indirim yapılması suretiyle, karlılığın azalmamasına da olanak tanımaktadır. Kolcu ve 
Yamak (2018:141)'e göre, konut kredisi faiz oranlarının kısa dönemde konut fiyatlarına negatif etkisi olduğu ve gelir düzeyinin uzun dönemde konut fiyatları üzerinde pozitif etkisi olmaktadır. Grafik 5'e bakıldığında, 2015 yılından 2019 yılına kadar konut birim satı̧ fiyatlarının, arsa payı dahil konut birim maliyetlerinin iki kat ve üzerinde seyir gösterdiği görülmektedir. Aynı dönemlerde ilk el satışların da iskanlı toplam konut üretiminin yüzde 70 - 80'i civarında olduğu görülmektedir. Diğer bir ifadeyle, konut üretiminde bulunan konut yatırımcıları, 2015 yılından 2019 yılına kadar maliyetlerin en az iki katı fiyatla konut satışlarını yapmış ve bu kar oranlarına sahip fiyatlardan toplam üretilen iskanlı dairelerin yaklaşık yüzde 70-80'inin satş̧ları gerçekleşmiş̧ir. Konut yatırımcılarının sahip oldukları bu karlılık ve yüksek satış oranlarının gerçekleşmesini sağlayan talep düzeyi, konu fiyatlarının belirgin bir azalma göstermemesinin önemli nedenleri olabilmektedir.

Türkiye Ekonomisi'nde konut talebinin istikrarlıllğını sağlayan birçok unsur olmakla beraber, konut yatırımcılarının karlılık düzeylerini arttırabilmesine olanak sağlayan da birçok yöntem uygulanmaktadır. Bu unsur ve yöntemler Koçarslan (2011)'a göre şunlardır;

Türkiye'de hanehalkı büyüklüklerinin yıllar itibariyle düşmekte olması düşük metrekareye sahip konut üretiminin yadırganmamasına sebep olmaktadır. Özgürlüğe düşkün bireysel yaşamın revaçta olması, boşanmaların artması gibi olgular, daha az metrekareye sahip evlerin talep edilmesine neden olmaktadır. Özellikle demografik değişimin hızlı olduğu illerde meydana gelen talep, sektörde satı̧s sorunu doğurmamaktadır.

Türkiye'de özellikle büyük konut yatırımcısı olan inşaat şirketleri tarafından önce inşaatı tamamlayıp sonra satmaya dayalı "yap - sat" anlayışı yerine, inşaata başlamadan önce maket üzerinden önce satış yapıp sonra inşaatı yapmaya başlamaya dayalı "sat - yap" anlayışı benimsenmektedir. Böylece tüketicilere yapılan ön satışlarla inşaata başlama maliyetleri dış kaynak kullanılmadan ya da olabildiğince az kullanılarak ve faiz maliyetlerine katlanılmadan ya da olabildiğince az katlanılarak karşılanabilmektedir. Bu şekilde yapılan satışlar, genelde orta ve üst gelir grubuna yapıldığından, bu alımı yapan tüketicilerin göreli olarak daha düşük fiyattan alım yapmaları sağlanmakta, bu yöntemle inşaat başlangıç maliyetlerinin finansmanı büyük ölçüde ön satışlarda elde edilen cirolardan karşılanmaktadır. Yatırımlık konut talebinde bulunan sınıftaki tüketicilerin yüksek peşinatları alındıktan sonra kredilendirilen tutarların vadesi genellikle yüksek faiz maliyetiyle yüzleşmemek için sene olarak oldukça kısa vadeler içerisinde tutulmaktadır. İnşaat şirketleri kısa dönemli senelik vadelere yönelik kendileri de kredilendirme yapmakta ve bankalardan kredi kullanımına göre daha cazip finansman olanakları yaratmaktadırlar. Konuta yönelik artan talebin varlığı, fiyatların düşmeyeceği kanısını da beraberinde getirdiğinden yatırımlık konut talebi de sürekli olmaktadır.

Arsa fiyatlarının artış gösterdiği dönemlerde, sektördeki firmalar genellikle projeye başlama maliyetlerini en aza indirebilmek amacıyla arsa alımları yerine, arsa sahipleri ile anlaşma yoluna giderek "sat-yap" sistemine dayalı konut üretim anlayışı ile hareket etmekte, mümkün olduğunca dış kaynak kullanmadan düşük maliyetli kaynak kullanımıyla proje inşaatlarına başlama yöntemlerini tercih etmektedirler ve bu durum da karlılıkların artmasına olanak vermektedir.

Sözü edilen tüm bu unsur ve yöntemler, istikrarlı talebe neden olan unsurlar ve konut sektöründe üretimde bulunan firmaların maliyet düşürme, dolayısıyla karlılık arttırma yöntemleri olmaktadır. Karlılığın yüksek olduğu bir piyasada, doğal olarak sektöre giren firma sayısı artmaktadır. Bununla beraber Koçarslan (2011)'e göre, rekabetin fiyatların düşmesine sebep olmaması için şirketlerin ürün farklılaşmasına giderek farklı ihtiyaçlara ve farklı çevrelerin ihtiyaçlarına yönelik projeler üretmeye başlamaları söz konusu olmaktadır. Bu durumdan kaynaklı olarak bazı inşaat firmalarının 
sadece rezidans ve villa inşaatlarına yöneldiği görülmekte, farklı ihtiyaçlara cevap verebilen yaşam alanlarının projelere dahil edilmesiyle fiyatların düşmesi bir ölçüde engellenmeye çalışılmaktadır. Türkiye'de konutların fiyatları yükseliyorken genel olarak satışı yapılan konutların metrekare değerleri de küçülmektedir. Genellikle bir kata ait kapalı alan inşaat yapılacak metrekare ne kadar fazla daireye bölünebiliyorsa, inşaat şirketleri her bir daireden daha yüksek gelir elde etme imkanına kavuştuklarından, her bir katta olabildiğince fazla sayıda bağımsız bölüm oluşturarak karlılık arttırmayı hedeflemektedirler. Daire metrekarelerinde yapılan azaltmaların pazarlama açısından doğurabileceği olumsuz etkiler, konut projelerindeki havuz, sosyal tesis vb. çeşitli yaşam alanlarının projelere dahil edilmesiyle bertaraf edilmeye çalışılmaktadır. Özellikle yeni yapılan site tipli konut projelerinde sıkça yer verilen yaşam alanları, konut fiyatlarını yükseltmede cazip bir pazarlama faktörü olarak kullanılmakta, oluşturdukları maliyetler ise çok daireli yapılarda bağımsız bölüm başına göreli olarak düşük bir parasal yük teşkil ettiğinden, bu alanların konut fiyatlarındaki arttırıcı etkisinden faydalanılarak karlılıkta artış sağlanması amaçlanmaktadır.

\section{Sonuç}

Çalışmada ele alınan yıllara ilişkin istatistiklere bakıldığında, konut sektöründe talebin istikrarlı olarak artış gösterdiği ve talep sorununun yaşanmamakta olduğu, üretilen iskanlı konutların yüksek oranlarda ilk el satışa konu olduğu görülmektedir. Ayrıca konut sektöründe inşaat maliyetlerine oranla iki kat ve üzerinde göreli yüksek karlılıklarla çalışılması, konut piyasasında arz fazlası olmasına rağmen, fiyatlarda düşme eğilimi oluşturmamakta, tam aksine fiyatların aşağı yönlü hareketinin sınırlı kalması ya da artması sonucunu doğurmaktadır. Yıllar itibariyle konuta olan istikrarlı talep ve üretici karlılığının yeni konut yatırımlarının artmasına neden olabilmesi de teoriye göre olağandır.

Yeni konut yatırım faaliyetlerinde bulunan inşaat şirketlerinin, maliyetlere göre karlılık oranlarının yüksek seyretmesi ve konutun istikrarlı bir talep görmesi, konut yatırımında bulunan şirketlerin, düşük dış kaynak kullanımı yaparak yüksek finansman maliyetlerine katlanmalarına gerek olmadan ve konut fiyatını düşürmeden faaliyetlerine devam etmelerinin bir dayanağı olabilmektedir. Geçmiş dönem karlılıkları, büyük konut yatırımcısı firmaların çok katlı ve yaşam alanlı konut projelerine başlamalarına rahatlıkla imkan verebilmekte ve böylece karlılıkların daha da artması sağlanabilmekte, karlılıkların yeni konut yatırımlarını bir döngü içinde zincirleme beslemesini doğurmaktadır. Maketten satışların yeterli sermayesi olan ve bina tamamlama sigortası yaptırabilen şirketlere tanınması, büyük konut yatırımcısı şirketlerin karlılıklarını ve toplam konut üretimini daha da arttırmasına olanak sağlamaktadır. Özellikle büyük şehirlerde konut üretiminde bulunan konut yatırımcısı büyük inşaat şirketlerinin markalı konut inşaatları, depreme dayanıklılık ve inşaatın tamamlanmasına yönelik güvenceler, konutları talep edenlerin de güvenlerini kazanmaktadır. Markalı ve yaşam alanlı konut yatırımcısı firmaların konut alıcılarına şirket olarak tanıdıkları ipotekli alımlarda düşük peşinat ve vade sürelerinin yüksek olması imkanları da talebi güvenli konut alımına yöneltmektedir.

Değinilen tüm bu hususlara bağlı olarak istikrarlı bir konut talebi ve karlılıklar nedeniyle, ekonomide konut arzı artarken konut fiyatları düşmemektedir. Bu sonuçtan hareketle, Türkiye'de konut yatırımlarının maliyetlere göre karlılık oranlarının yüksekliği ile bu karlılığın yeni karlı konut yatırım projelerinin kaynağı olabilmesi ve döviz kuru artı̧ beklentisinin varlığı konut fiyatlarının düşmemesinde belirleyici faktörlerden bazıları olarak sayılabilir. 


\section{Kaynakça}

Eryüzlü, H., Ekici, S., 2020. Konut fiyat endeksi ve reel döviz kuru ilişkisi: Türkiye örneği. İktisadi İdari ve Siyasal Araştırmalar Dergisi, 5(12), 97-105. Erişim: https://dergipark.org.tr/tr/download/article-file/1137340

Golland, A., 1996. Housing supply, profit and housing production: the case of the United Kingdom, the Netherlands and Germany. Netherlands journal of housing and the built environment, 11(1), 5 .

Gözübüyük, S., Koy, A., 2020. Türkiye'de konut üretiminin belirleyicileri: ekonomik büyüme ve konut faiz oranı. Bankacılık ve Sermaye Piyasası Araştırmaları Dergisi, 4 (9), 1-10. Erişim: https://dergipark.org.tr/tr/pub/bspad/issue/55354/747789

Hatipoğlu, Ü., \& Tanrıvermiş, H. (2017). Türkiye'de arz ve talep açısından konut yatırım tercihlerini etkileyen faktörlerin değerlendirilmesi. Bankacılar Dergisi, (100), 49-75.

Hazine ve Maliye Bakanlı̆̆ (2020). Bina metrekare normal inşaat maliyet bedelleri. Erişim : https://www.alomaliye.com/kategori/diger-mevzuat/m2-maliyetleri/

Knight Frank, 2020. Global Konut Fiyat Endeksi, Erişim : https://www.knightfrank.com/research

Koçarslan, Nesrin, 2011. Konutta Arzı Yönetenler Erişim : http://docplayer.biz.tr/980310Yonetenler-arzi-konutta-86-infomag-mart-2011-fotograf-lorem-ipusm.html:

Kolcu, F., Yamak, N., 2018. Gelir ve faiz oranlarının konut fiyatları üzerindeki kısa ve uzun dönem etkileri. Uluslararası Íktisadi ve İdari Incelemeler Dergisi, 141-152 . Doi: 10.18092/ulikidince.439535

Mishkin, F.S., 2018. Makroekonomi Politika ve Uygulama. Ankara: Nobel Yayınc1lık.

Timetürk, 2008. Erişim : https://www.timeturk.com/tr/2008/02/28/muteahhite-kat-karsiligiarsa.html

Trading Economics, 2020. Indicators, USA, Core Inflation Rate, Erişim : https://tradingeconomics.com/united-states/core-inflation-rate

Tunç, Cengiz, 2020. Konut Piyasası, Finansmanı Ve Göstergeleri. İstanbul: Literatür Yayıncılık

Türkiye Cumhuriyet Merkez Bankası. (2020). Elektronik Veri Dağıtım Sistemi, (EVDS), Konut ve İnşaat İstatistikleri. Erişim: https://evds2.tcmb.gov.tr/index.php?/evds/serieMarket/collapse_26/5949/DataGroup/turki sh/bie_hkfe/

Türkiye Cumhuriyet Merkez Bankası. (2020). Elektronik Veri Dağıtım Sistemi, (EVDS), KurlarDöviz Kurları - ABD Doları Döviz Satış İstatistikleri. Erişim: https://evds2.tcmb.gov.tr/index.php?/evds/serieMarket/collapse_26/5949/DataGroup/turki sh/bie_hkfe/

Türkiye Cumhuriyet Merkez Bankası. (2020). Elektronik Veri Dağıtım Sistemi, (EVDS), Beklenti Anketi İstatistikleri - Cari Yıl Sonu Bankalararası Döviz Piyasası ABD Dolar Kuru Beklentisi Erişim:http://www.tcmb.gov.tr/wps/wcm/connect/TR/TCMB+TR/Main+Menu/Istatistikle r/Egilim+Anketleri/Beklenti+Anketi+Istatistikleri 